\title{
Death of a Theory
}

James Bullard

The author discusses the effectiveness of fiscal approaches to stabilization policy. The conventional wisdom before 2007 was that fiscal policy intervention as a stabilization tool had little to recommend it, mostly due to political constraints and to the unlikely effectiveness of many types of temporary fiscal policy actions. However, with short-term nominal interest rates near zero, attention turned again toward fiscal stabilization policy. The author describes and critiques two theories of how fiscal policy might be viewed as effective in such circumstances. One, heavily studied, is that a tax-financed increase in government expenditures would temporarily increase total output in the economy. The other, lightly studied but rhetorically forceful, is that increased government expenditures may inspire confidence. Both theories have drawbacks, but the author argues the first is dying because of three considerations: (i) actual political systems are ill-suited to implement the advice from the theory; (ii) monetary stabilization policy has been quite effective, making fiscal experiments redundant; and (iii) governments pushed distortionary taxes into the future, which in the theory reduces or eliminates the desired effects. (JEL E4, E5)

Federal Reserve Bank of St. Louis Review, March/April 2012, 94(2), pp. 83-101.

n early 2009, I published a paper entitled "Three Funerals and a Wedding." In it, I described how the financial crisis up to that point had changed the conventional wisdom on some critically important macroeconomic issues facing the nation. While there were several items in the funeral category, there was just one item in the wedding category-just one "idea on the rise": fiscal policy as a macroeconomic stabilization tool.

I was rather perplexed by the intellectual return of what I considered to be somewhat outdated fiscal stabilization policy concepts. Yes, the nature of taxation along with the level and composition of consolidated government spending are important for macroeconomic performance. But the conventional wisdom over the two decades leading up to the financial crisis has been that fiscal policy was in fact not a good tool for macroeconomic stabilization-not a good way to attempt to react to shocks that buffet the economy. Instead, the thinking went, fiscal authorities should focus on a stable taxing and spending regime that makes sense economically and politically over the medium and longer run. Shorter-run stabilization issues should be han-

James Bullard is president and CEO of the Federal Reserve Bank of St. Louis. Any views expressed are his own and do not necessarily reflect the views of other Federal Open Market Committee members. This article was originally prepared for a lecture to the Korean American Economic Association at the ASSA meetings in Chicago, January 7, 2012. The author appreciates the helpful comments received at that event and the hospitality provided by the KAEA; he also appreciates helpful comments from the St. Louis Fed research staff.

( ) 2012, The Federal Reserve Bank of St. Louis. The views expressed in this article are those of the author(s) and do not necessarily reflect the views of the Federal Reserve System, the Board of Governors, or the regional Federal Reserve Banks. Articles may be reprinted, reproduced, published, distributed, displayed, and transmitted in their entirety if copyright notice, author name(s), and full citation are included. Abstracts, synopses, and other derivative works may be made only with prior written permission of the Federal Reserve Bank of St. Louis. 


\section{Bullard}

dled - to the extent that the effects of important macroeconomic shocks can be mitigated at allby the monetary authority. This state of affairs lasted, broadly speaking, until the fall of 2008 .

At that point, the short-term nominal interest rate targeted by the Federal Open Market Committee (FOMC) was pushed nearly to zero, where it remains to this day. This led many to conclude that the burden for short-term macroeconomic stabilization had shifted to fiscal policy.

Now, three years later, we have seen numerous attempts at stabilization policy by fiscal authorities not just in the United States, but throughout many of the countries in the Organisation for Economic Co-operation and Development (OECD). Indeed, we have seen this around the globe. In this article I will argue that the net effect of these attempts has been to confirm much of the conventional wisdom regarding fiscal stabilization policy that existed up to 2007. In short, existing political processes are, generally speaking, far too cumbersome and contentious to enact effective and timely short-term actions in response to market events. They are ill-equipped to deliver the types of subtle tax and spending interventions that may actually be effective according to a careful reading of the available macroeconomic literature on the topic.

I will describe and comment on two strands of the macroeconomic literature in this area, one highly formalized and the other intuitive but rhetorically potent. The first is the heavily studied fiscal multiplier idea in the context of New Keynesian DSGE 2 macroeconomics. The second is less studied and not formally articulated very often. It is that a substantial increase in deficit-financed government purchases sends a signal to the private sector that a high growth regime is possible - and likely - going forward. This could influence private sector expectations and lead to a virtuous equilibrium in which actual output and employment are high. Rhetorically, this seems to be what many advocates have in mind, even if this is not what happens inside most of the macroeconomic models used to analyze this issue.

Mostly with the first theory in mind, I turn to a discussion of actual events over the past three years. I argue that the actual fiscal policy experiment undertaken during this period in many countries has departed in an important way from the advice given in the mainstream macroeconomics literature. In particular, while the mainstream literature suggests that taxfinanced increases in government spending during the period of financial turbulence may be effective, actual policymakers used debt-financed government spending, implicitly pushing distortionary taxes into the future and arguably undoing the positive effect that was otherwise predicted to occur. In addition, initial debt conditions were far from the pristine ones often studied in the macroeconomics literature. The idea that there may be such a thing as "too much borrowing" by a sovereign has been analyzed in the macroeconomics literature but is typically not discussed on the academic side of the fiscal stabilization policy debate. I discuss how the literature suggests limits on sovereign debt that could bind in some circumstances.

In the meantime, monetary policy has proven to be remarkably able to continue to conduct stabilization policy even when the policy rate has been near zero in the G-7 countries. According to the literature I review here, an effective monetary policy at the zero lower bound suggests that a turn toward fiscal stabilization policy is redundant.

These considerations suggest that the conventional wisdom on fiscal stabilization policy will now reassert itself. Tax and spending policies are important; but the goal should be to provide a stable environment in the medium and longer run, not to react to macroeconomic shocks. 


\section{CONVENTIONAL WISDOM UPSET}

\section{The Thinking Pre-2007}

In a 1992 paper, N. Greg Mankiw, a self-described Keynesian economist, mused about the differences between modern Keynesian thinking and older Keynesian views from earlier in the postwar era. ${ }^{3}$ In it, he described six dubious old Keynesian propositions, one of which was this: "Dubious Keynesian Proposition \#4: Fiscal policy is a powerful tool for economic stabilization, and monetary policy is not very important." The source of the problem was political: "In the U.S. today, fiscal policymakers have completely abdicated responsibility for economic stabilization. Their inability to cope with persistently large government deficits has left them unable even to imagine trying to reach consensus on countercyclical fiscal policy in a timely fashion. All attempts at stabilization are left to monetary policy."

I thought Mankiw's description at the time had it exactly right and in fact was not really even controversial. Stabilization policy means reacting to macroeconomic shocks that hit the economy in a timely manner and in a way that produces some desired absorption of the shock, thus smoothing out an otherwise rocky ride for the economy's businesses and households. It seems obvious that existing political processes will not be of the type that can easily react in a timely and subtle way to macroeconomic shocks.

Of course it does matter for macroeconomic performance overall what choices are made at all levels of government for the consolidated U.S. tax system and for the size and composition of government spending. It is just that attempting to change tax and spending decisions in a timely way in response to shocks is not practical and will probably not work well. So, an important corollary to this line of thinking is that fiscal policy should focus on the medium and the longer run. In particular, tax and spending decisions should be set in a way that fosters maximum economic growth over the medium and longer run and that garners enough political consensus to remain stable over long periods of time. In this way, private sector expectations of fiscal policy will be as consistent as they can be with actual tax and spending decisions, and this will aid private sector decisionmaking and improve economic prospects.

One way to see how far we are from this ideal is to consider Leeper (2010). Leeper argued that the uncertainty surrounding future tax and spending programs is pervasive and costly to the United States: "In this era of fiscal stress, fiscal expectations are unanchored and fiscal alchemy creates unnecessary uncertainty..." He cites data from the CBO, reproduced in Figure 1. The chart shows projected debt-to-GDP ratios for the United States made in 2009 and 2010. In

some scenarios, the debt-to-GDP ratio runs to several hundred percent of GDP. This is not really feasible: The future tax and spending plans associated with that scenario would have to be considered completely unspecified by today's market participants. This uncertainty has important effects on today's behavior of businesses, households, and financial markets.

\section{Monetary Policy Hits the Zero Lower Bound}

In December 2008, the existing conventional wisdom as I have described it was ruptured when the FOMC set the policy rate at 0 to 25 basis points, effectively arriving at the zero lower bound on nominal interest rates. Moreover, the Committee soon announced that the near-zero rate policy would continue for an "extended period." It meant a funeral for nominal interest rate 


\section{Figure 1}

\section{Projections of U.S. Federal Government Debt as a Percentage of GDP}

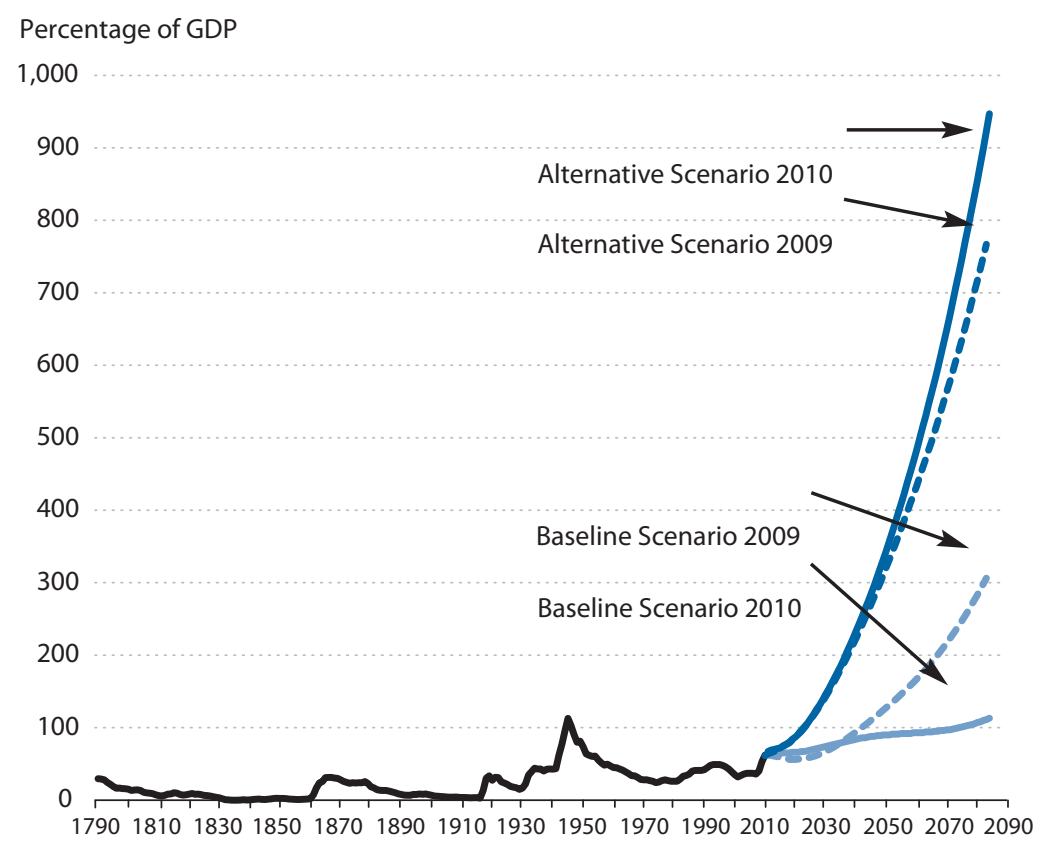

SOURCE: Congressional Budget Office $(2009,2010)$

targeting, and indeed market expectations today call for the FOMC to remain at the near zero policy rate for some time to come. (See Figure 2.)

A key issue that immediately arose was whether monetary stabilization policy could still be conducted effectively at the zero lower bound on nominal interest rates. If it could, then there would be less need to move toward fiscal programs for stabilization, because the existing conventional wisdom-leave it to monetary policy - would still be valid. But, if monetary stabilization policy could no longer be conducted effectively, then it might mean that the fiscal authorities would have to step in to provide the desired reaction to macroeconomic shocks, to the extent that any stabilization at all is possible when the economy is hit by a large shock.

I think it is fair to say that for many in monetary policy circles and financial markets who were weaned on nominal interest rate targeting as the sine qua non of monetary policy action, the initial assumption was that monetary policy would not be effective at all once the zero bound had been reached. Accordingly, interest shifted rapidly to the use of fiscal policy for stabilization purposes, despite the known political difficulties such a strategy would entail based on the thenexisting conventional wisdom described above.

To say that monetary stabilization policy cannot be effective once the zero lower bound has been encountered is to say that the central bank cannot create inflation once this condition is met. In the New Keynesian DSGE models I describe here, this is indeed the case and, in those models, the alternative way to create inflation is to get output to increase, which in certain cir- 


\section{Figure 2}

\section{Policy Rates in the G-7 Countries}

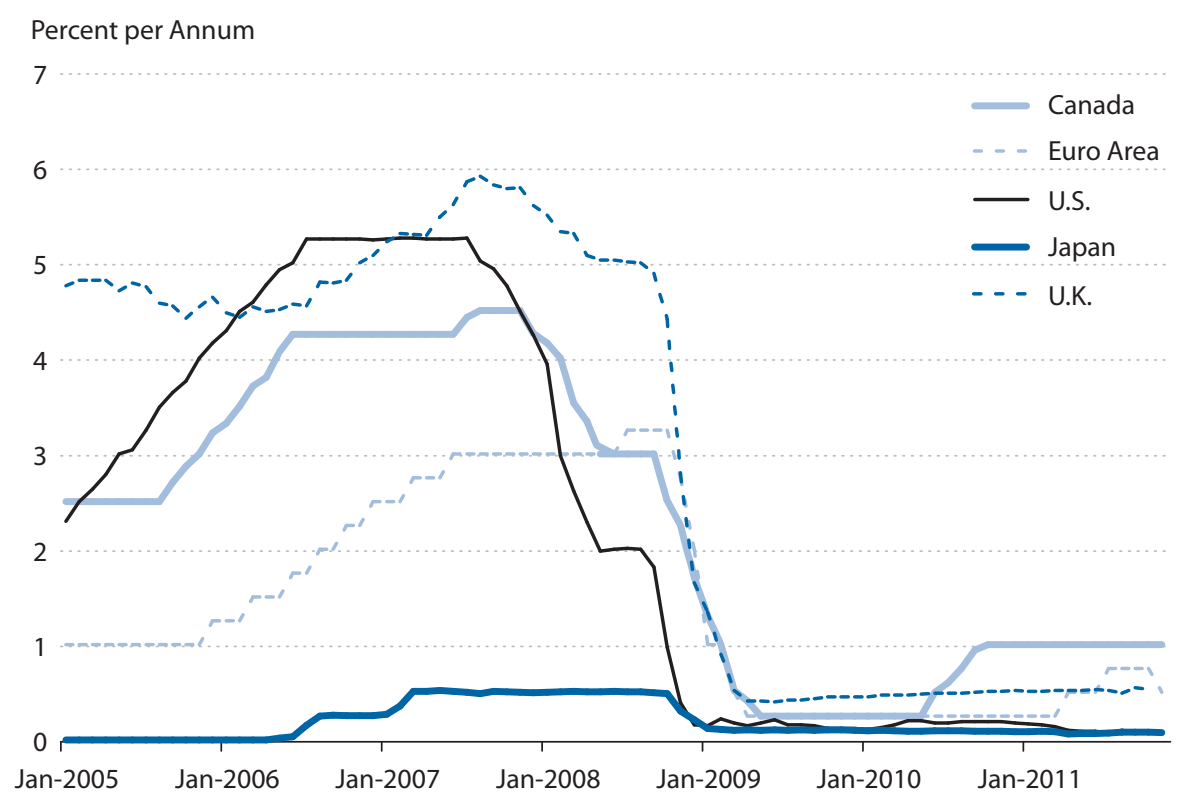

NOTE: These rates were lowered to near the zero lower bound in late 2008 and early 2009 and remain very low today.

cumstances then puts upward pressure on inflation. So, the goal is to create more output as a way to get more inflation. Higher inflation and expected inflation is useful at the zero lower bound because, with nominal rates at zero, higher inflation means lower real rates of return, which by conventional definitions is stimulative monetary policy. It is a roundabout way to influence inflation expectations, but there you have it.

Still, if monetary policy remained effective as a stabilization tool even at the zero lower bound, then the central bank could simply influence inflation expectations directly and one would not have to resort to the fiscal channel through "Dubious Keynesian Proposition \#4." And indeed, many have argued that monetary policy retains an extensive array of options even when the zero bound on nominal interest rates is encountered, not least of them Chairman Bernanke, who states, a "principal message...is that a central bank whose accustomed policy rate has been forced down to zero has most definitely not run out of ammunition." $\underline{4}$

During the past three years, the FOMC has had the opportunity to put these ideas to the test. The Committee has adopted an array of policy actions that have substituted for conventional monetary policy conducted through nominal interest rate targeting. These policy actions have included, principally, quantitative easing (QE), most recently during the first half of 2011. The results have been that inflation and inflation expectations remain today near the Committee's implicit inflation target of 2 percent, even though there have been a variety of forces that might have suggested much lower inflation rates or outright deflation during this period. Arguably, monetary policy has been successful at influencing inflation and inflation expectations during 
this period, and therefore it is not so clear as it may have seemed three years ago that a turn toward fiscal policy as a stabilization tool was warranted. Similarly, the United Kingdom, with its own quantitative easing program, has been able to avoid very low or negative inflation rates even though arguably the impact of the financial crisis was more intense there.

The literature on monetary stabilization policy when the policy rate is at the zero lower bound is generally supportive of the effectiveness of QE policies. $\frac{5}{\text { Yet }}$ in the baseline New Keynesian DSGE literature, the leading theory in the area, such policies are typically ineffective. $\underline{6}$ This situation reminds me of a paraphrase of something Ronald Reagan used to say-namely, that an economist is a person who sees something work in reality and wonders if it works in theory. My judgment is that the discrepancy between the existing theoretical results and the existing empirical evidence says more about the weakness of the assumptions being used to build the theory. ${ }^{7}$ In particular, in the theory as it is normally presented, the central bank can buy unlimited amounts of Treasury securities and other assets through base money creation without creating any inflation. This is at odds with the international experience over hundreds of years.

\section{Could Fiscal Stabilization Policy Be Effective?}

Let us now focus on what the New Keynesian DSGE literature has to say about fiscal approaches to stabilization policy. Here, I will rely on the admirable summary provided by Woodford (2011). Woodford's approach is to begin with a very simple framework in which increases in government spending do not expand total real output in the economy and then add features to illustrate some of the cases where increases in government spending may be effective in expanding total real output.

The thought experiments contemplated in Woodford (2011) involve funding an increase in government expenditures today with lump-sum taxes today. The main question is whether such a policy could raise real output today. The increased output would be matched by increased labor supply. Lump-sum taxes are not connected to particular economic decisions and in this sense are non-distortionary. Accordingly, the lump-sum taxes case represents the most favorable situation with regard to the success of the policy. Actual taxes are in fact distortionary in the sense that imposing new taxes changes economic decisionmaking. This point is emphasized by Uhlig (2010) and Drautzburg and Uhlig (2011). They argue that including distortionary taxation in a realistic way will make the benefits of fiscal expansion espoused in the New Keynesian literature much smaller or, possibly more likely, negative. But for now, let us go with the lumpsum tax assumption in order to understand what is being said in the New Keynesian approach to fiscal stabilization policy.

As is typical in the New Keynesian literature, the baseline model is of a closed economy and there is no investment in most of Woodford's summary. $\underline{8}$ The composition of government spending is generally ignored, but with the understanding that we begin with a situation in which the consolidated government is providing an efficient level of government goods and services, such that the marginal value of a dollar allocated to the public sector is equal to the marginal value of a dollar allocated to the private sector. This level could be expressed as a percent of GDP. The fiscal policy stabilization experiment is to then, in certain circumstances, increase government spending beyond this level with an eye to returning to the optimal level later. So, by itself, there 
will be some distortion from this stabilization policy coming solely from "too much" government expenditure during the period of fiscal expansion, but the argument is that the business cycle stabilization benefits will outweigh this negative effect. $9, \underline{10}$

For those less familiar with the macroeconomic literature, tax-financed increases in government spending may not seem promising relative to debt-financed increases in expendituresthat is, deficit spending. However, it has been well understood in the macroeconomics literature for decades that because households and businesses are forward-looking, they will naturally foresee future taxes and that these expected future taxes can affect behavior today. Because of this, whether the increase in spending is financed through taxes today or through taxes in the future that pay off a debt incurred today is largely irrelevant. Extreme forms of this ideaRicardian equivalence-suggest that the offset would be perfect. But even apart from the most extreme formulations, it is fairly difficult to avoid the Ricardian reality in a macroeconomic policy setting. Households and businesses do look ahead and do worry about the future tax environment. Woodford's approach is all squarely within the Ricardian tradition and so is very much mainstream macroeconomics in this sense.

For freshwater macroeconomists of a certain age, Woodford begins by presenting an intuitive, familiar, and reassuring finding. In particular, if the model is simple enough, such that there is no sticky price assumption and therefore no role for monetary stabilization policy whatsoever, then temporary increases in government expenditure like the one described above will not be expansionary. The fiscal multiplier will be less than one and expansion of government spending during a recession is to be discouraged because it will cause real output to decline further. This sounds like a version of Barro's (2009) view, who argues that even the military build-up during World War II had a fiscal multiplier less than one.

If one is willing to add to the model the controversial Calvo-style sticky price assumptionmantra in some quarters, but anathema in others-things get considerably more complicated. Sticky prices can be thought of as a restriction that allows firms to revisit their pricing schedules only once in a while, instead of continuously. So, while prices are being adjusted over time, prices do not continuously reflect exactly the supply and demand conditions in each market at each point in time in the macroeconomy. Adding the sticky price assumption to the model means that monetary policy will have a well-defined role to play in offsetting shocks to the economy through movements in nominal short-term interest rates.

Woodford's central point is that in this more complicated and perhaps more realistic environment, the effect of an increase in government spending like the one described above depends on the reaction of monetary policy, because the monetary authority has some influence over the real interest rate, owing to the failure of goods and services prices to completely adjust immediately. While one has to postulate what this reaction might be, some types of inept monetary policies would create an environment in which the tax-financed increase in government spending would increase output. This would occur because the monetary authority was not fully pursuing optimal policy, and because of this there would be a role for the fiscal authority to play. But to the extent that monetary stabilization policy was fully optimal-shocks to the economy are offset exactly to the extent they can be offset - there would be no room left for additional fiscal stabilization policy. In fact, going the fiscal route would be less desirable because it would in reality involve distortionary taxation and because, at least in the model, the amount of govern- 


\section{Bullard}

ment goods and services being produced would be beyond the level that would otherwise be optimal for the economy; thus, it would disturb the division of production between the public and the private sectors.

Accordingly, it is not just sticky prices alone but also monetary policy encountering the zero lower bound that create the situation where the case in favor of fiscal stabilization policy comes into play in the New Keynesian DSGE framework. At the zero lower bound it may be argued that the monetary authority cannot pursue optimal monetary policy anymore, because, at least inside the model, once the zero bound is encountered there is little the central bank can do to influence the real interest rate. Strictly speaking, this assertion is not true even inside the New Keynesian framework, since the central bank could make credible commitments to keep the policy rate near zero for a period somewhat longer than otherwise expected and could through this mechanism conduct an appropriate monetary policy that would eliminate the need to turn to fiscal policy for macroeconomic stabilization purposes. In fact, this idea has been a part of the FOMC's actual policy since 2008, first through the "extended period" language and more recently through the "at least through mid-2013" language in the Committee's statements. So, in addition, one has to assume that this type of promise is not effective either, perhaps because the central bank does not have the ability to make the appropriate type of commitment far into the future. With this additional assumption, then, one can argue that there may be room for fiscal stabilization policy through a program of increased government spending financed by lumpsum taxes.

Woodford (2011) stresses that any expansionary effects on real output through increases in government spending would be dramatically more important during periods in which financial markets, for reasons exogenous to the model, are not functioning "normally." For the fiscal multiplier arguments, this is a very important point: While a case could be made of the type just described above in less extraordinary times, the fiscal multipliers calculated are sometimes only marginally greater than one, calling into question the whole enterprise. $\stackrel{11}{ }$ With disrupted financial markets, the multipliers tend to be much larger, and thus the case is that much stronger. In addition, the empirical evidence of substantial financial market disruption during 2008 and 2009 is very strong. Figure 3 shows the evolution of the St. Louis Financial Stress Index during this period. The index, which basically aggregates a variety of indicators of financial turmoil including interest rate spreads and the VIX, was essentially off the charts during the winter of 2008-09. A reading of zero would mean normal stress levels and a reading of 2 would be exceptionally high by historical standards; during the crisis readings of 5 or higher were observed. By 2010, however, stress had returned to more normal levels, and so the case for continued increases in government spending at that point had diminished.

In summary, the case for fiscal stabilization policy as presented by Woodford (2011) has, above all, a certain delicate quality to it. 12 As Woodford (2011, p. 33) notes, "[W]hile a case for aggressive fiscal stimulus can be made under certain circumstances, such policy must be designed with care if it is to have the desired effect." To me, it is the design with care clause that is so contrary to the rambunctious and contentious U.S. political process that is supposed to settle on the program in a timely manner. It is in this sense that the conventional wisdom outlined earlier has seemed to reassert itself during the past three years. Yet there are at least two other aspects 


\section{Figure 3}

\section{St. Louis Financial Stress Index}

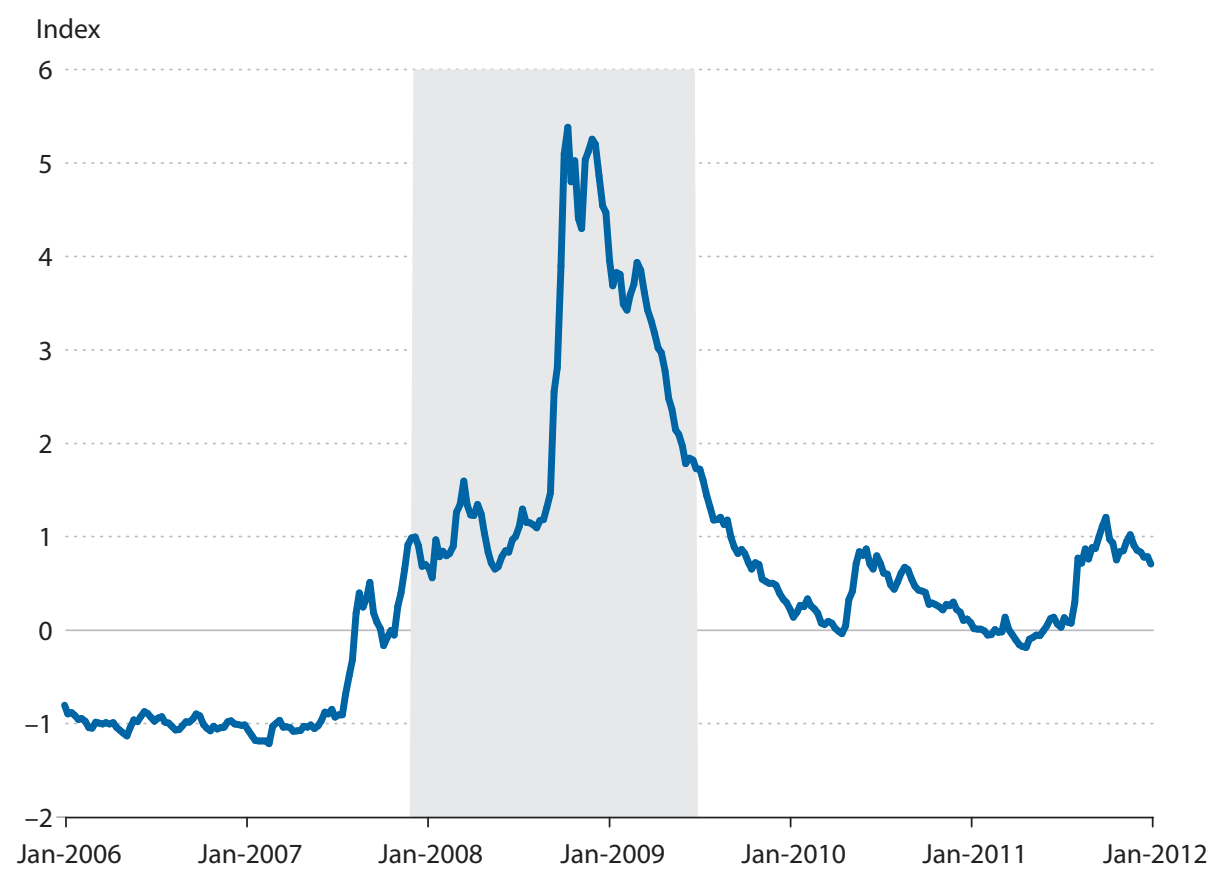

NOTE: Financial stress was extraordinarily high during 2008 and 2009, and Woodford (2011) suggests that certain types of fiscal policy intervention could be very effective in such circumstances. Stress had returned to more normal levels by 2010. http://research.stlouisfed.org/fred2/series/STLFSI.

of the New Keynesian DSGE story regarding fiscal stimulus that lead me to doubt its validity for the present circumstances.

One involves the interaction between monetary and fiscal policy. The story critically depends on the idea that monetary policy becomes ineffective and unable to influence real rates of return in the economy once the zero bound on nominal interest rates is encountered. Yet as I pointed out earlier, many have argued exactly the opposite, chief among them Chairman Bernanke. And it certainly appears that the FOMC has been far from being out of ammunition during the past three years, with many of the Committee's unconventional policies regarded as quite successful. $\underline{\underline{13}}$ Inflation and inflation expectations, in particular, have remained higher than might have been expected given other developments in the economy. This suggests that the Committee is quite able to run an effective countercyclical monetary policy while the policy rate remains near zero by using means other than ordinary nominal interest rate adjustment to influence financial con-

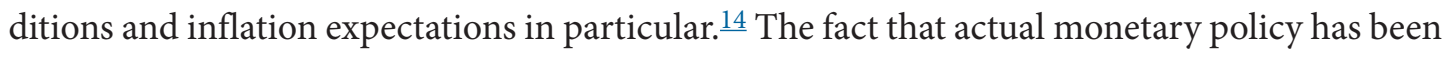
effective means that one of the key assumptions underlying the theory of effective fiscal stabilization policy (i.e., ineffective monetary policy) has not been met. And, as Woodford (2011) stresses, one would not want to go the fiscal route unless it was really necessary, because it involves other distortions, including the temporary diversion of resources to the public sector and the imposition of distortionary taxes. $\underline{\underline{15}}$ 


\section{Bullard}

A second important aspect of the result from the literature turns back to the issue of distortionary versus lump-sum taxation. With a more realistic distortionary taxation assumption (such as an increase in the rate of taxation of labor income), the fiscal policy intervention-the extra spending and taxation-would properly be occurring only during the period of distressed financial markets and a near-zero policy rate and not any longer than that. In the model, the taxes are collected at the same time that the government spending is ramped up; it is a "balanced budget" intervention. If, instead, the taxes are collected during later periods, this would greatly mitigate or eliminate altogether the effectiveness of the program. So, despite the fact that all of this analysis is within the Ricardian tradition, the timing of the program does matter. This aspect of the results will be important when we consider the actual policy experiment in many countries.

Overall, even if one is willing to accept a fairly long list of simplifications and assumptions (all of which could be challenged), the message seems to be that it is a fairly subtle matter to get exactly the right fiscal policy program in place that would produce the desired effects. In addition there are clear caveats, including not least the detrimental effects if the taxes that are to be levied are distortionary and the possible effects on investment. As a consequence, even to the extent one is willing to accept the entire line of analysis as an illuminating way to think about the issue, it is still fairly subtle in reality to implement the policy.

\section{An Alternative Theory}

The rhetoric surrounding the fiscal stabilization policy debate can sometimes be somewhat different from the discussion in academic settings. In some of the rhetoric, it sounds like analysts are advocating for an aggressive fiscal action as a way to send a signal to the private sector in the economy. This signal would jolt the economy out of its slow growth state and into a self-sustaining recovery. This type of story would put more emphasis on changes in private sector expectations concerning macroeconomic prospects in reaction to the fiscal policy intervention and less emphasis on a mechanical reaction of the economy to increases in taxes and spending.

There is an alternative theory that could be studied more formally that captures some of the spirit of this rhetoric. We could think of the alternative theory as follows. There are two possible regimes for the economy, one characterized by relatively rapid growth in real output and the other characterized by slow growth. Markets clear in both regimes, and in this sense there are multiple equilibria for the economy. Switching between the two regimes is due entirely to private sector expectations - that is, expectations of high growth lead to private sector decisions that are consistent with high growth, but expectations of low growth lead to private sector decisions that are consistent with low growth. Government spending, and in particular increased government borrowing, might be taken as a signal that the economy is likely to switch to the high growth state soon, because borrowing means that the government foresees plenty of income in the future available to pay back debt. If this signal is widely believed in the economy, then private sector decisions may be made that are consistent with the high growth regime, the expectations will be self-fulfilling, and the equilibrium where the economy grows rapidly will be the outcome.

This basic type of idea has been common in macroeconomics over the past 25 years and has gained somewhat in popularity over time, although I am not aware of a direct application to the fiscal stabilization policy debate. It certainly has not been the focus of attention in the many attempts to evaluate fiscal policy intervention over the past several years. However, a theory with this basic structure may be closer to what many have in mind. $\underline{16}$ 
Running up a lot of sovereign debt, for instance, would make sense if real income in the future is expected to be much higher than real income today. In that situation one would want to borrow from the future to help smooth consumption between today and tomorrow. The debt run-up might be interpreted as demonstrating confidence in the future productive capacity of the economy. In turn, this might affect private sector expectations of future productive capacity and lead to coordination on a high growth equilibrium.

While this is possible, there is also an important downside in a model of this type. Increases in sovereign debt may not be interpreted as reliably indicating that future growth will be strong. Instead, the increased spending might be viewed as wasteful and the run-up in government debt might suggest that the low growth regime, not the high growth regime, is the one that will prevail in the future. In such a situation, the economy will coordinate on the low growth regime instead of switching to the high growth regime. So, in the end growth would be slow and the economy would be saddled with a lot of debt that would be difficult to repay. There is a high price to pay if the attempt to signal confidence in the future does not work.

\section{The Actual Policy Experiment}

The actual fiscal stabilization policy experiment over the past several years in Europe and the United States does not look like the increase in government expenditures financed by nondistortionary lump-sum taxes described in Woodford's (2011) baseline model. Governments for the most part did not impose taxes and instead borrowed on global markets. Figure 4 illustrates what selected countries actually did during the crisis years from 2007 to 2009. The figure shows the deficit-to-GDP ratio on the horizontal axis and the debt-to-GDP ratio on the vertical axis. Readers may wish to keep in mind that the limits set in the Maastricht treaty establishing the European Central Bank (ECB) put the suggested maximum deficit-to-GDP ratio at 3 percent and the maximum debt-to-GDP ratio at 60 percent. The idea behind those limits was that they could be viewed as sustainable over the long term in economies that have sufficient economic growth along with real interest rates that are low enough. The left panel shows that while a few countries may have been adhering to the Maastricht guidelines as of 2007 (the lower-left endpoint of each line segment), by 2009 every country was in violation of one or both guidelines (the upper-right endpoint of each line segment). The right panel shows that, while the situation improved during subsequent years with respect to the deficit-to-GDP ratio (lower-right endpoints), debt-to-GDP ratios have continued to rise (the upper-left endpoints).

In Woodford (2011), the word "debt" occurs just once. This is because, within the setting analyzed there and in most of the literature, there is nothing special about government borrowing, as it indicates only that taxes will be collected in the future in such a way that the net present value of taxes and expenditures are equal. Debt might represent a problem only to the extent that it means that the proposed increases in government spending today are not being matched by taxes collected during the same period, but instead distortionary taxes will be levied in the future at a point when the crisis has passed. As noted above, this shifting of the tax collection into the future is problematic for the effectiveness of the program, as it can mitigate or eliminate the potential benefits.

But there is another issue. As Figure 4 illustrates, the initial debt conditions of many countries were far from pristine before the crisis began in 2007. Embarking on fiscal expansion meant 
Figure 4

Debt and Deficits Relative to GDP

2007-2009

Debt-to-GDP Ratio

220

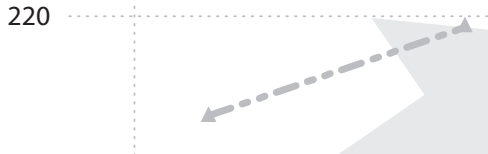

170

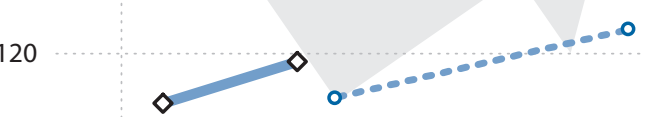

70

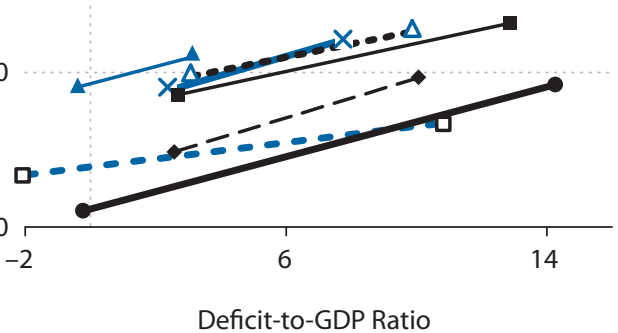

2009-2011 (p)

Debt-to-GDP Ratio

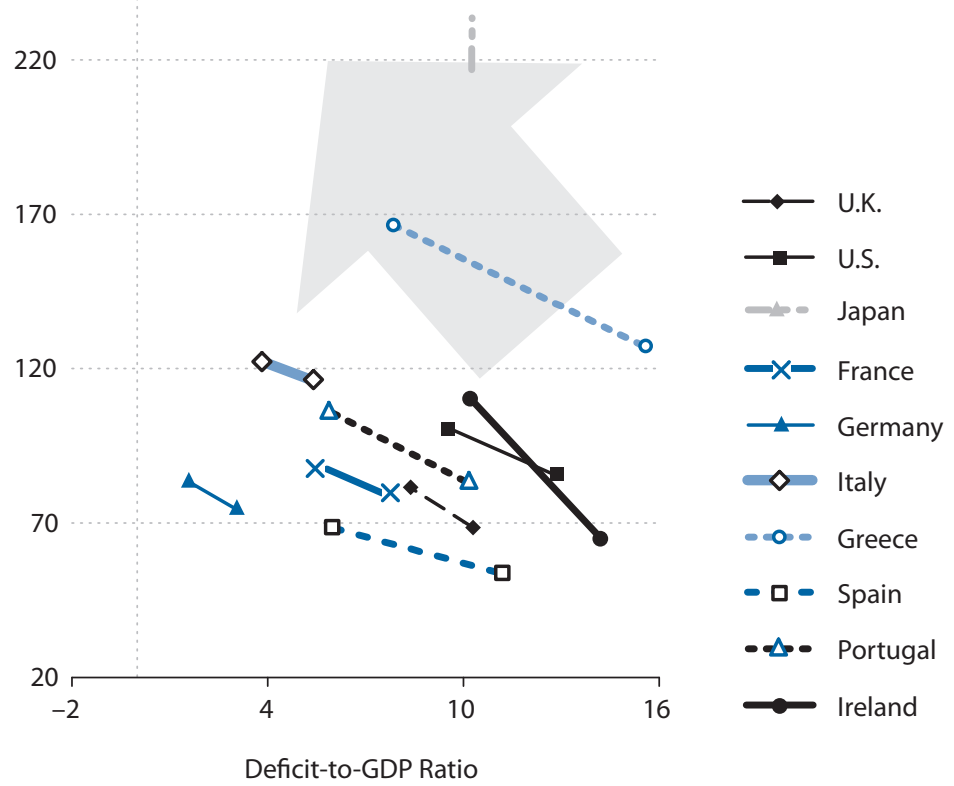

NOTE: Left panel: In most countries, deficit-to-GDP and debt-to-GDP ratios increased during the crisis. Right panel: More recently deficit-toGDP ratios have fallen, but debt-to-GDP ratios continue to rise. 2011 data are projected (p). Adapted from Contessi (2012).

pushing debt-to-GDP ratios far above those normally considered sustainable, at least by Maastricht standards. The theories I have outlined so far say nothing about the concept of "too much debt." Yet, too much debt is exactly the problem that has been created.

\section{Debt Sustainability}

Countries can and do take on too much debt. Sovereign default on debt has been a regular feature of the international macroeconomic scene for centuries. $\frac{17}{}$ Countries that look like they may default are initially charged a higher interest rate, which worsens their fiscal outlook. But it is probably not simply the interest rate itself that is the most important concern from a sustainability standpoint. International markets will compute the amount they think will likely be repaid by a sovereign nation, and countries will have difficulty borrowing beyond these limits. In the macroeconomics literature these limits are known as endogenous debt constraints. $\frac{18}{\text { In }}$ many models, these constraints are not calculated. Instead, we often assume that the sovereign nation can borrow unlimited amounts on international markets at the going interest rate. Such an assumption works well when discussing relatively small changes to debt levels, but becomes strained for the types of policy experiments illustrated in Figure 4. 
Markets attempting to compute the appropriate loan size can consider the types of sustainability conditions described, for instance, in Ley (2010) and Contessi (2012). The key ideas are that, first, a great deal depends on expectations of the future and also that considerations such as the expected real growth rate of the economy and the expected real interest rate are critical. Since everything is forward-looking, one has to be careful about the nature of the assumptions about the future spending and taxing patterns in a given economy. There are many different spending and taxation patterns that are possible over a long horizon- say, 50 years. A nation could, for instance, borrow today, increase government spending today, but dramatically cut government spending and taxation in the future in such a way that the net present value of expenditures is equal to the net present value of tax revenues. In some quantitative models, such a program, if it was completely credible, would produce a boom in real output today. Because of this type of consideration, it is perhaps unwise to make blanket statements about debt run-up necessarily being good or bad for the economy, as it depends on the context of likely future developments in tax and spending policy over the medium and long run.

The key issue from the perspective of macroeconomic models is that the debt increases in the United States since 2008 were undertaken without any political consensus concerning the future tax or spending regime. Without a clear statement about future tax and spending regimes, it is difficult to evaluate the situation. Still, I think nearly all observers of the U.S. political situation assume that it is exceedingly difficult to raise tax levels much above where they are today or to reduce spending commitments in a significant way in the future. Any changes that might actually be made are likely to be marginal, the bare minimum necessary to continue the existing status quo with regard to both taxes and spending to the extent possible.

If the expansion of government debt is not consistent with this political reality, then international markets will begin to limit the amount they are willing to lend to the sovereign. The endogenous debt constraint clashes with the political reality, and one side or the other has to give in. Since political processes usually change only very slowly, it is the international markets that abandon the sovereign. Yes, interest rates rise; but more than that, the market is not really interested in lending to the sovereign at any price. The debt limit has been reached. No more.

In macroeconomic models, the sovereign faces a certain indifference condition at the endogenous debt constraint. $\frac{19}{}$ On one hand, the sovereign could elect to default at any point in time. This would provide a benefit in the sense that the outstanding debt amount can simply be consumed without having to be repaid. The loan becomes a grant. But the penalty for default is that, in the future, access to capital markets will be severely limited. In models, this is sometimes a permanent exclusion from credit markets, but other less severe penalties are possible. The sovereign can weigh how badly it needs access to international credit markets in the future against the temporary benefits of default. At the endogenous debt constraint, the sovereign is exactly indifferent between these two possibilities. In addition, international markets understand this condition and will not lend to the sovereign beyond this amount.

The endogenous debt constraint could be relatively low for some countries but relatively high for others. The nature of the constraint would depend on expected real growth rates, expected real interest rates, expected paths for government spending and taxes, and an evaluation of the political process in the country. All of this evaluation goes on every day in international financial markets. 


\section{Bullard}

Does this help us decide how much debt is "too much" for a sovereign? I think it does in the sense that there will certainly be some limit, and it will be determined by the situation where temporary advantages to default by the sovereign outweigh the present value of continued access to international credit markets. Maastricht laid down a very simple and practical set of criterianamely, a debt-to-GDP ratio below 60 percent and a deficit-to-GDP ratio below 3 percent-that could be calculated using rule of thumb assumptions about growth, real interest rates, and other factors. Today, many large industrial nations are well beyond these limits and so we have a crisis. Moreover, it will take many years to return debt-to-GDP ratios to lower levels, and so the crisis will remain with us for a long time. The United States is far from immune and has some of the worst numbers in the group. $\underline{20}$

Again, international markets will likely lend to a sovereign at the going market rate if the debt level is well inside the sustainability conditions defined by an endogenous debt constraint. Outside this constraint, no lending will occur at any price, since in that case international markets will see that the incentive of the sovereign is to default - that is, that the advantages to default outweigh the advantages of continued access to international credit markets for that nation. Where the constraint lies certainly does depend on interest rates, but yields by themselves are probably not the best indicator of whether further borrowing by a sovereign is warranted or not. A look at the data confirms this.

Figure 5 shows the spread of yields on sovereign debt of selected European countries relative to Germany from 2000 to the present. In every case, up to 2007, these spreads were quite low. Using the narrow spread data from 2000 to 2007 as an indicator that these countries had no problem with excessive debt levels, and therefore could borrow even more, turned out to be badly mistaken. In fact, further borrowing during 2008 and 2009 put these countries into crisis situations, and the rates required to borrow or roll over debt on international credit markets increased dramatically. This same situation faces the United States, as analysts sometimes point to low borrowing costs as evidence that further borrowing could be carried out at low risk to the economy. Why not borrow more since markets do not seem to be charging a very high interest rate? But Figures 5 suggests that very low rates are not a good predictor of how close a country may be to a debt constraint.

Of course, default does not have to be viewed in a binary way. Partial default is certainly possible and can take many forms. "Surprise" inflation is one of these forms-a scenario in which the actual inflation experienced over the lifetime of the loan exceeds the inflation rate expected when the loan was consummated. In this situation, some advantage accrues to the borrower at the expense of the lender, and in this sense it can be viewed as a method of partial default. Some analysts advocate surprise inflation as a magical method of fixing excessive debt problems for sovereign nations.

There are at least three problems with this view. First, it is not clear how effective surprise inflation would be in situations where some of the debt issue is indexed to inflation and much of the outstanding debt matures over relatively short time horizons during which inflation does not tend to change appreciably. Second, it is not that easy to generate the "surprise" inflation component necessary for this story, since international markets are keenly attuned to inflation data and monetary policy moves. To the extent inflation can be anticipated, it will create a premium in the yield at the date of issue. And third, the threat of surprise inflation would create an 


\section{Figure 5}

\section{Sample of 10-Year Government Bonds Relative to German Bonds}

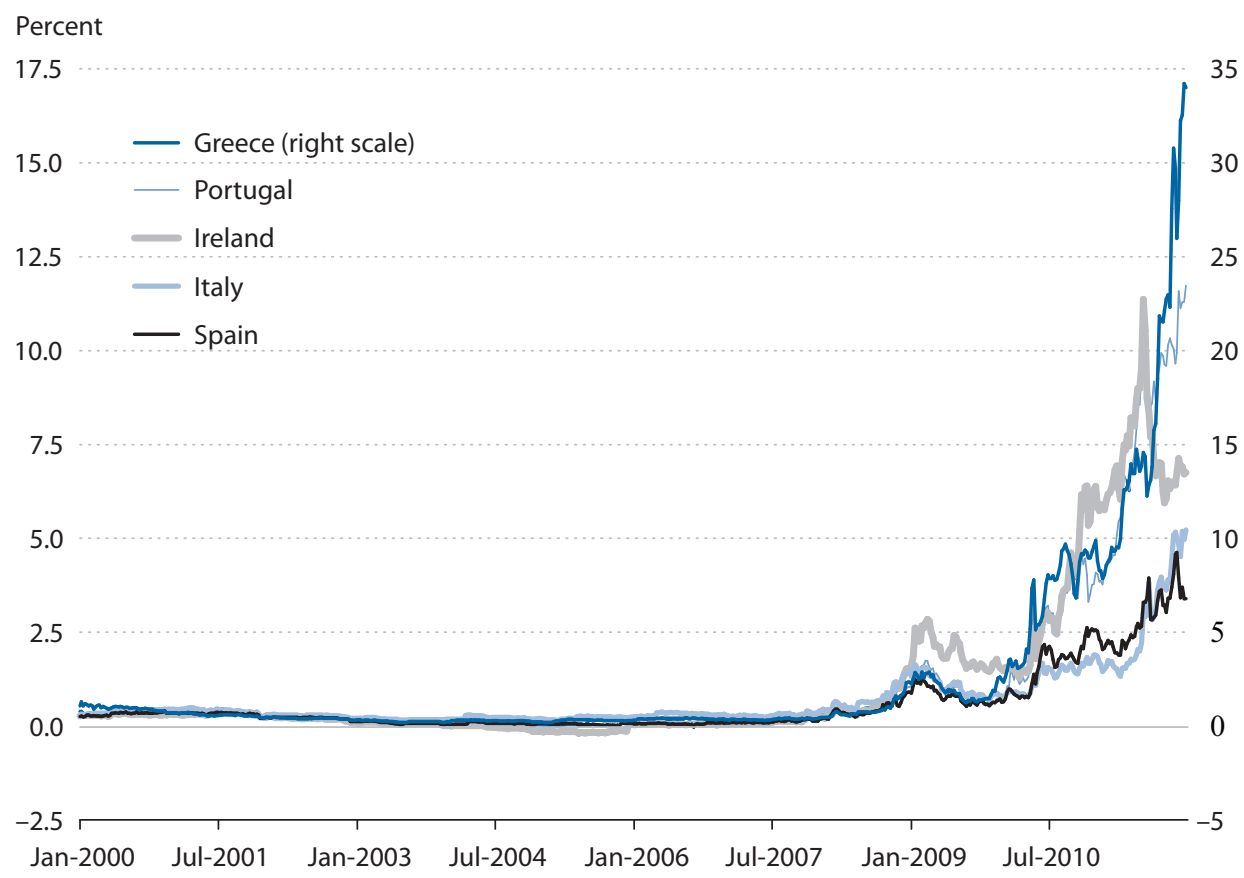

inflation risk premium in yields. The inflation risk premium would likely have to be paid for many years, until the central bank was able to regain credibility that it was not planning to create another surprise inflation.

One of the main ideas behind the creation of the euro was exactly that by creating a panEuropean ECB with German credibility, all member countries would be able to borrow at lower rates because there would be little threat of surprise inflation and so inflation risk premia would be very low. Surprise inflation in Europe would have the opposite effect, requiring all euro area members to borrow at higher rates as euro-based inflation risk premia would rise.

\section{CONVENTIONAL WISDOM RE-ESTABLISHED}

Fiscal policy as a macroeconomic stabilization tool has enjoyed renewed popularity over the past several years, contrary to a conventional wisdom that had been established during the two decades before the financial crisis that began in 2007. However, the conventional wisdom is turning out to be correct after all, and so the theory is dying.

The academic case for turning to fiscal policy to offset macroeconomic shocks can be made in a New Keynesian DSGE model in which certain assumptions hold. In this article, I have largely accepted the New Keynesian story as it is usually told-I have not tried to challenge the many 


\section{Bullard}

assumptions that lie behind the analysis, even though one could take that approach as well. Instead, I have argued that, even accepting most of the analysis, one should have considerable doubt about the merits of possible fiscal stabilization programs.

I have argued that there are three key problems: (i) The types of fiscal policy interventions recommended in the literature are fairly intricate and must be designed carefully if they are to have the desired effect. This delicacy is at odds with the conventional wisdom on fiscal stabilization policy as I have laid it out, which emphasizes that political processes in the United States and elsewhere are not well-suited to make timely and subtle decisions like this. (ii) The theory critically relies on monetary policy being ineffective once the zero bound is encountered, but many have argued that the zero-bound constraint does not limit present-day monetary policy because there are many other tools that the monetary policy authority can use to influence inflation and inflation expectations. In fact, many analyses of FOMC policy over the past three years have suggested that monetary stabilization policy has been fairly effective. (iii) The actual fiscal stabilization policy experiment did not involve funding increased government spending with lump-sum taxes, as contemplated in the theory, but instead involved heavy borrowing on international markets. In models, the borrowing would be interpreted as promised future distortionary taxes, but it is exactly the shifting of distortionary taxes into the future beyond the period of the binding zero lower bound and financial market turbulence that can undo most or all of the benefits that might otherwise come from the fiscal stabilization program.

A fourth problem is less apparent from a reading of the literature. The substantial increases in sovereign debt levels over the past several years have raised the concern that there is "too much debt." This is not normally mentioned on the academic side of the fiscal stabilization policy debate, but there is certainly a large literature on endogenous debt constraints that gives clear perspective. The perspective is that there will definitely be such a thing as "too much debt" for a sovereign, and it will be defined by the point where the temporary benefits of default exactly offset the present value of continued access to international credit markets. According to the literature in the area, markets will understand the incentive to default and so will not lend beyond the constraint. The value of the constraint will depend on many factors, and debt yields alone are probably not the best way to evaluate whether a nation is about to encounter a constraint.

I conclude that the recent turn toward fiscal approaches to stabilization policy has run its course. The conventional wisdom of the past several decades is reasserting itself because it has proved to provide wise counsel. Stabilization policy should be left to the monetary authority, which can operate effectively even at the zero lower bound. Fiscal policy should return to being set for the medium and longer run. A stable tax code that does not change very often lays down the rules inside the macroeconomy and allows businesses and households to make investments effectively. In addition, a government spending program that adds up over a 50-year time horizon increases confidence that the tax code will not have to be altered too much going forward. 


\section{NOTES}

1 See Bullard (2009).

2 DSGE stands for dynamic stochastic general equilibrium and represents the standard in the current literature.

3 See Mankiw (1992).

4 See Bernanke (2002, italics in original).

$\underline{5}$ For my views on QE2 in particular, see Bullard (2011), a presentation at the Quantitative Easing Conference, Federal Reserve Bank of St. Louis. Papers at the conference generally supported QE2 effectiveness. See Gagnon et al., (2011), Neely (2011), Hamilton and Wu (2011), Joyce et al., (2010), and D'Amico and King (2011).

$\underline{6}$ For a detailed discussion of this issue from the theoretical viewpoint, see Curdia and Woodford (2010).

$\underline{7}$ One promising avenue for future research is provided by Williamson (2011). Williamson suggests that cash is useful in retail transactions, but government-issued debt is useful in wholesale transactions, a separate market. Open market operations that swap cash for debt then reduce the debt available for wholesale transactions, creating a "shortage."This drives up prices of debt and reduces real yields.

$\underline{8}$ In some of the quantitative-theoretic New Keynesian literature, investment is included. See, for example, Christiano, Eichenbaum, and Rebelo (2010). Also, Leeper et al. (2011) find evidence of negative investment multipliers in estimated DSGE models with investment.

9 Many readers may feel strongly that consolidated government expenditure is already either far too high or far too low, depending on your point of view. However, the appropriate size of government is not the issue being addressed here, as the analysis concerns stabilization policy-that is, how the government should react to a large shock, in the spirit of assuming that everything was fine before the shock occurred.

10 Expenditures such as unemployment benefits can be rationalized as insurance schemes separately from the business cycle considerations discussed here. For discussions of fiscal stabilization policy in models with search unemployment, see Campolmi, Faia, and Winkler (2011) and Monacelli, Perotti, and Trigari (2010).

11 That is, the increase in government spending would have the desired positive effect on real output, but the magnitude of the effect can be so small that, given all the uncertainty lying behind the calculation, one might decide not to make the attempt.

12 Another version of the delicate nature of the fiscal multiplier result is given by Erceg and Lindé (2010). In their paper, larger fiscal programs have correspondingly smaller fiscal multipliers.

13 See endnote 4 .

14 This is very different from the Great Depression scenario in the United States in which nominal interest rates also fell to zero but the Federal Reserve sat on its hands while a substantial deflation of about 10 percent per year took hold.

15 Many readers may be thinking, why not do both? But that is a misunderstanding of what is being said in the available literature. The government spending is meant to substitute for the missing monetary policy at the zero bound by doing the same thing that monetary policy would otherwise do-namely, lower the real interest rate. If monetary policy is already doing that, then there is no purpose to "doing both."It is like a driver of a car with a passenger. If the first driver gets tired, you can switch drivers. But few would suggest both trying to drive the car at the same time as a way to improve driving performance. In the model, the increase in government expenditures ultimately works through an increase in inflation expectations. But an effective monetary policy is, in part, trying to keep those same inflation expectations at an appropriate level. Accordingly, nothing "extra" is being contributed by fiscal policy.

16 For one interesting analysis, see Farmer (2012).

17 See, for instance, Reinhart and Rogoff (2009).

18 For some discussion see, for example, Bulow and Rogoff (1989), Kehoe and Levine (1993), and Azariadis and Lambertini (2003).

19 For an analysis of the effects of debt constraints in emerging markets, see Cuadra, Sanchez, and Spariza (2010).

$\underline{20}$ One analysis that provides an alternative perspective on "too much" sovereign debt is from Cecchetti, Mohanty, and Zampolli (2011). In that paper, the authors attempt to estimate a threshold sovereign debt level beyond which the effects on economic growth begin to turn negative. This is another way of thinking about where the limits to debt accumulation may lie. The authors use panel data from the OECD. According to their estimates, the threshold occurs at a debt-to-GDP ratio of about 90 percent. I thought this was a helpful estimate. 


\section{Bullard}

\section{REFERENCES}

Azariadis, Costas and Lambertini, Luisa. "Endogenous Debt Constraints in Lifecycle Economies." Review of Economic Studies, July 2003, 70(3), pp. 461-87.

Barro, Robert J. “Government Spending Is No Free Lunch." Wall Street Journal, January 22, 2009; http://online.wsj.com/article/SB123258618204604599.html.

Bernanke, Ben. “Deflation: Making Sure 'It' Doesn't Happen Here." Remarks before the National Economists Club, Washington, DC, November 21, 2002; www.federalreserve.gov/boarddocs/speeches/2002/20021121/default.htm.

Bullard, James. "Three Funerals and a Wedding." Federal Reserve Bank of St. Louis Review, January/February 2009, 91(1), pp. 1-12; http://research.stlouisfed.org/publications/review/09/01/Bullard.pdf.

Bullard, James. "QE2: An Assessment." Presented at the Quantitative Easing Conference, Federal Reserve Bank of St. Louis, June 30, 2011; http://research.stlouisfed.org/econ/bullard/pdf/Bullard_QE_Conference_June_30_2011_Final.pdf.

Bulow, Jeremy and Rogoff, Kenneth. "Sovereign Debt: Is to Forgive to Forget?" American Economic Review, March 1989, 79(1), pp. 43-50.

Campolmi, Alessia; Faia, Ester and Winkler, Roland. "Fiscal Calculus in a New Keynesian Model with Labor Market Frictions." Working Paper No. 2011/5, 2011, Magyar Nemzeti Bank; www.mnb.hu/Root/Dokumentumtar/MNB/Kiadvanyok/mnbhu mnbfuzetek/WP 2011 05.pdf.

Cecchetti, Stephen G.; Mohanty, M.S. and Zampolli, Fabrizio. "The Real Effects of Debt," in Achieving Maximum Long-Run Growth. Presented at the 2011 Economy Policy Symposium, Jackson Hole, Wyoming, August 25-27, 2011; www.kc.frb.org/publicat/sympos/2011/2011.Cecchetti.paper.pdf.

Christiano, Lawrence; Eichenbaum, Martin and Rebelo, Sergio. "When Is the Government Spending Multiplier Large?" Working paper, Northwestern University, 2010.

Contessi, Silvio. "Sovereign Debt Sustainability and the Current Debt Crisis." Federal Reserve Bank of St. Louis Review, 2012 (forthcoming).

Cuadra, Gabriel; Sanchez, Juan M. and Sapriza, Horacio. "Fiscal Policy and Default Risk in Emerging Markets." Review of Economic Dynamics, April 2010, 13(2), pp. 452-69.

Curdía, Vasco and Woodford, Michael. "Conventional and Unconventional Monetary Policy." Federal Reserve Bank of St. Louis Review, July/August 2010, 92(4), pp. 229-64; http://research.stlouisfed.org/publications/review/article/8272.

D'Amico, Stefania and King, Thomas B. "Flow and Stock Effects of Large-Scale Treasury Purchases." Federal Reserve Board of Governors Division of Monetary Affairs, February 2011; www.frbsf.org/economics/conferences/1102/amico-king.pdf.

Drautzburg, Thorsten and Uhlig, Harald. "Fiscal Stimulus and Distortionary Taxation." NBER Working Paper No. 17111, National Bureau of Economic Research, July 2011; www.nber.org/papers/w17111.pdf.

Erceg, Christopher J. and Lindé, Jesper. "Is There a Fiscal Free Lunch in a Liquidity Trap?" Federal Reserve Board of Governors International Finance Discussion Paper No. 1003, July 2010; www.federalreserve.gov/pubs/ifdp/2010/1003/ifdp1003.pdf.

Farmer, Roger. "The Stock Market Crash of 2008 Caused the Great Recession: Theory and Evidence." Journal of Economic Dynamics and Control, 2012 (forthcoming).

Gagnon, Joseph; Raskin, Matthew; Remache, Julie and Sack, Brian. "Large-Scale Asset Purchases by the Federal Reserve: Did They Work?" Federal Reserve Bank of New York Economic Policy Review, May 2011, pp. 41-59; www.newyorkfed.org/research/epr/11v17n1/1105gagn.pdf.

Hamilton, James D. and Wu, Jing C. "The Effectiveness of Alternative Monetary Policy Tools in a Zero Lower Bound Environment." Unpublished manuscript, University of California at San Diego and University of Chicago, May 2011; http://dss.ucsd.edu/ jhamilto/zlb.pdf.

Joyce, Michael; Lasaosa, Ana; Stevens, Ibrahim and Tong, Matthew. "The Financial Market Impact of Quantitative Easing." Working Paper No. 393, Bank of England, 2010; www.bankofengland.co.uk/publications/workingpapers/wp393.pdf.

Kehoe, Timothy J. and Levine, David K. "Debt-Constrained Asset Markets." Review of Economic Studies, October 1983, 60(4), pp. 865-88.

Leeper, Eric M. "Monetary Science, Fiscal Alchemy," in Macroeconomic Challenges: The Decade Ahead. Presented at the 2010 Jackson Hole Economic Policy Symposium, Jackson Hole, Wyoming, August 26-28, 2010;

www.kc.frb.org/publicat/sympos/2010/2010-08-16-leeper-paper.pdf. 
Bullard

Leeper, Eric M.; Traum, Nora and Walker, Todd B. "Clearing Up the Fiscal Multiplier Morass." NBER Working Paper No. 17444, National Bureau of Economic Research, and Indiana University, 2011; www.nber.org/papers/w17444.pdf.

Ley, Eduardo. “Fiscal (and External) Sustainability." Economic Policy and Debt, PREM, World Bank, July 2010; http://siteresources.worldbank.org/INTDEBTDEPT/Resources/468980-1207588563500/4864698-1207588597197/FSPrimer.pdf.

Mankiw, N. Greg. “The Reincarnation of Keynesian Economics." European Economic Review, April 1992, 36(2-3), pp. 559-65.

Monacelli, Tommaso; Perotti, Roberto and Trigari, Antonella. "Unemployment Fiscal Multipliers." Journal of Monetary Economics, July 2010, 57(5), pp. 531-53.

Neely, Christopher J. "The Large-Scale Asset Purchases Had Large International Effects." Working Paper No. 2010-018C, Federal Reserve Bank of St. Louis, July 2010; http://research.stlouisfed.org/wp/more/2010-018.

Reinhart, Carmen M. and Rogoff, Kenneth. This Time Is Different: Eight Centuries of Financial Folly. Princeton, NJ: Princeton University Press, 2009.

Uhlig, Harald. "Some Fiscal Calculus." American Economic Review, May 2010, 100(2), pp. 30-34.

Williamson, Steven. "Liquidity, Monetary Policy, and the Financial Crisis: A New Monetarist Approach." American Economic Review, 2011 (forthcoming).

Woodford, Michael. "Simple Analytics of the Government Expenditure Multiplier." American Economic Journal: Macroeconomics, January 2011, 3(1), pp. 1-35. 
Close

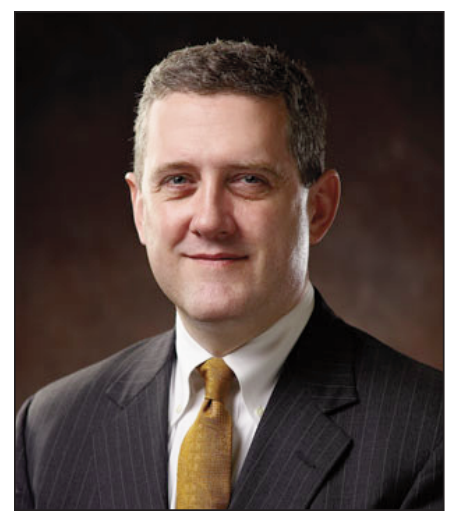

James Bullard

President and CEO of the Federal Reserve Bank of St. Louis

http://research.stlouisfed.org/econ/bullard/ 